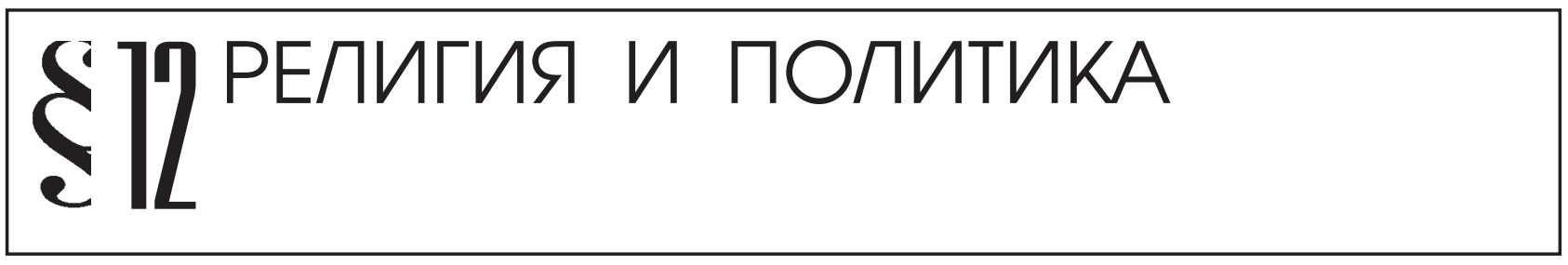

Палюлин А.Ю.

\title{
ВЛИЯНИЕ ИТАЛЬЯНСКИХ ГНОСТИКОВ НА ПОЛИТИКО-ПРАВОВЫЕ СОБЫТИЯ СРЕДНЕВЕКОВОЙ ЕВРОПЫ
}

\begin{abstract}
Аннотация: В настоящем исследовании затрагивается духовное учение ряда школ и направлений гностического характера, которые в своей совокупности составляли серьезную оппозицию утвердившейся в средние века в Европе римо-католической Церкви. Автор рассматривает противостояние гвельфов и гибеллинов не только в политическом аспекте, но и в качестве двух духовных сил, каждая из которых стремилась и имела возможности для установления своего правового режима в итальянских государствах. В данной статье рассмотрены предпосылки восстаний в Милане, Брешии и Риме в ХІІ-ХІІІ веках, отразивших настроения образованной части итальянского общества и недовольства правовыми принципами духовной инвеституры. Принципы организации папской и императорской власти были предметами оживленных дискуссий, нашедших свое отражение в буллах и банах, а также в политико-правовых трактатах. Автором рассматриваются последствия противостояния гностических и католических воззрений, нашедших свое отражение как на политической карте Европы, так и в памятниках европейского права.

Review: The present research covers teachings of a number of Gnostic schools which altogether created a serious opposition to medieval Rome Catholic Church in Europe. The author describes the opposition between Guelphs and Ghibellines not only as part of politics but also as the two forces each of which had an opportunity to establish their legal regimes in Italian countries. The author of the article also considers grounds for rebellions in Milan, Brescia and Rome in XII-XIII centuries. The principles of organization of the Pope's and Emperor's powers were the subject of lively discussions reflected in bullas and bans as well as political and legal treaties. The author views consequence of this opposition between Gnostic and Catholic views reflected both on the political map of Europe and European law monuments.

Ключевые слова: юриспрудениия, альбигойцы, арнольдисты, вальвассоры, гибеллины, гностицизм, инквизиция, катары, папство, францисканць
\end{abstract}

Keywords: law studies, Albigenses, Vavasours, Ghibellines, followers of Arnold of Brescia, Gnosticism, Inquisition, Cathars, papacy, Franciscans.

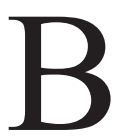
о многом благодаря влиянию христианской Церкви после падения Римской империи варварские королевства смогли установить иерархию власти и построить государственность в соответствии с устоями христианства. Две власти, светская и церковная, стали прочным фундаментом для будущих национальных государств Европы. Однако, несмотря на быстрое распространение, догматическое христианство не было единствен- ной философией, строящей отношения внутри государства при помощи церкви.

Антиподом христианства в Средневековой Европе выступила гностическая ересь, именуемая катаризмом (от греч. К $\alpha \theta \alpha \rho o i ́)$, что означает «чистые, неосквернившиеся». Примечательно, что катарские идеи являются отклонением от христианства настолько ранним, что Лев Карсавин вообще не считает их христианами, считает их чуждыми религиозной жизни средне- 
вековой Европы ${ }^{1}$. Катары являются уникальным продуктом социополитической жизни северной Италии, и их истоки не могут быть отысканы в новоманихействе или восточном гностицизме. Катаризм типичен для западного христианства и выражает недогматические, антихристианские убеждения западных христиан. Эти мысли и веяния не могли быть высказаны в рамках римско-католической церкви, поэтому катаризм объективизируется и становится мощным идейным течением XI-XIII веков. Однако, с первых веков христианства, отколовшийся от изначальной веры катаризм жил своей собственной жизнью, до XI века, когда катарские и католические апологеты снова сталкиваются друг с другом, уже в качестве не только религиозных соперников, но и соперников политических, спорящих не только о догме, но и о праве.

Еще в 1041 году, как утверждают «Барийские анналы» ${ }^{2}$, в Италии появились еретики-павликиане, прибывшие, по всей видимости, из Малой Азии и упоминающиеся в связи с норманнскими войнами на юге Апеннинского полуострова.

Хроника Ландульфа Старшего описывает столкновение католиков и катаров в Ломбардии в 1027 году. Что характерно, ересь приобретает политический характер: архиепископ Ариберт из Милана узнает о ереси в замке Монфорте около Асти. Рауль Глабер в своем труде «Пять книг истории своего времени» (“Тhe five books of the Hostories") пишет, что Монфорт «был полон знатными людьми, которых так запятнало еретическое лжеучение, что легче им было кончить жестокою смертью, чем отвратиться от него к целебнейшему учению Господа Христа» ${ }^{3}$. Несмотря на то, что еретиков сжигали, искоренения ереси не происходило, так как она нашла поддержку не только у народа, но и у знати, видевшей политические преимущества в вере, которая не обязывает их слушаться папу, а самое главное - уплачивать церковные налоги.

Катары не признают иерархии римско-католической церкви. Они полагают, что ни священники, ни сам папа не могут давать отпущения грехов. Римской церкви еретики противопоставили свою церковь, рассеянную по миру, но, по их мнению, святую. Ка-

\footnotetext{
1 Карсавин Л.П. Очерки средневековой религиозности // История ересей: [сб.] / сост. А. Лактионов. - М.: АСТ, 2007. -572, [4] c.

${ }^{2}$ Annales barenses // MGH, SS. Bd. V. Hannover. 1844, p. 5156.

${ }^{3}$ Цит. по: Л.П. Красавин, указ. соч. С.13.
}

тары невольно обращали на себя внимание. Суровая аскеза, постоянный пост и воздержание воскрешали в умах людей воспоминания о древнем христианстве, не запятнанном стяжательством церкви и грехами ее последователей. Аскетические и благородные с точки зрения морали верования катаров стали весьма привлекательным учением для итальянского дворянства не только с позиций выгоды, но и с точки зрения традиционной христианской религиозности. Авторитет папства и всей католической церкви оказался под большой угрозой.

Когда в 1027 году в Милане на большой площади еретикам предоставили выбор: поклониться кресту или прыгнуть в огромный костер, многие из них бросались в пламя, "misere morientes in miseros cieneres redacti sunt”" («жалко умершие, в жалкий пепел превратились»). Данное действие осталось в памяти миланцев и повлекло за собой немалый интерес к катаризму.

Бедность и аскетизм привлекают на свою сторону многих католиков. Известный итальянский проповедник Арнольд Брешианский вскрывает стяжательство римско-католической церкви и призывает клир отречься от мирских богатств. «Не могут, - говорил он, - спастись клирики, обладающие собственностью, епископы - регалиями, монахи - владениями. [...] Народ не должен исповедовать им свои грехи, лучше исповедоваться друг другу; не должен принимать от них таинства. [...] Будут лживые учителя. Алчно будут они наживаться от вас, стремясь к наслаждениям, роскошествуя с вами на пирах своих с полными сладострастия глазами. [...] Что такое папа, презревший небесное ради земного? - Он не муж апостольский и пастырь душ, а муж крови, покровительствующий пожарам и убийствам, мучитель церквей, гонитель невинности. Он ничего не делает, только пасет тело, да наполняет свои кошельки и опустошает чужие... Не следует его слушать и почитать». ${ }^{5}$ Подобные опасные для римско-католической церкви заявления были усилены идейным союзом Арнольда с Пьером Абеляром, французским философом и теологом, утверждавшим, что церковь может заблуждаться, и любая официальная догма церкви может оказаться ошибочной, а истинны только Священное писание и диалектика. Воззрения Арнольда беском-

\footnotetext{
${ }^{4}$ Rodulfi Glabri Historiarum Libri Quinque; Rodulfus Glaber, The Five Books of the Histories [cover title: Rodulfus Glaber, Opera] ed. J. France (Oxford, 1989), p.108.

${ }^{5}$ Цит. по: Л.П. Карсавин. Указ.соч. С.76.
} 


\section{Политика и общество $7(103) \cdot 2013$}

промиссны и радикальны. Никакая уступка со стороны папства не склонила бы его к перемирию с церковью, поскольку идеалом его была церковь древняя, нищая и святая.

Политический диспут союза Арнольда Брешианского и Пьера Абеляра с одной стороны и высших иерархов церкви во главе с Бернардом Клервосским с другой стороны был не просто вопросом веры или догмы. В разрешении данного вопроса были прямо заинтересованы светские феодалы и император, равно как и духовные феодалы во главе с папой римским. Решался вопрос финансовой зависимости церкви от паствы и вопрос о дальнейшей судьбе имущества церкви. Арнольд был широко поддержан как низами общества, так и феодалами, торгово-промышленной буржуазией, не желавшей платить налоги церкви. Подобные же баталии в сфере отношений церкви и государства развернулись и в Православии в XV веке, на Руси. Идеи бедности церкви поддерживал Нил Сорский, а позднее - Вассиан Патрикеев и Максим Грек с партией «нестяжателей». Русские подвижники повторили судьбу Арнольда Брешианского и Пьера Абеляра, проиграв в политической баталии «иосифлянам» - сторонникам идей Иосифа Волоцкого о полезности монастырского землевладения. В 1531 году «нестяжатели» были признаны еретиками, часть из них была отправлена в ссылки, часть - заточена в монастыри.

В 1140 году на соборе в Сансе Бернард Клервосский предал анафеме учение Абеляра и Арнольда. Папа Иноккентий II осудил их учения как еретические, предписал заточить Арнольда и Абеляра в монастыре, их книги - сжечь.

Окончание перемирия между арнольдистами и папой было отмечено революцией в Риме, когда римская церковь потерпела поражение от сил арнольдистов, вальвассоров (феодалов, находящихся внизу феодальной пирамиды) и в целом сил, враждебных римской церкви. Если до этого момента союз гибеллинов и еретиков был случаен и обосновывался общими целями, такими как ослабление власти папы, финансового могущества римской церкви, то римская революция 1143 года - результат потребности светских феодалов в церковной реформе, акт необходимости политического и духовного преобразования церкви. Арнольд, непосредственно участвовавший в организации восстания, возлагал большие надежды на императора и Сенат. Он считал, что вся власть должна находиться исключительно в руках императора и предлагал ввести светскую инвеституру - изменить порядок назна- чения духовных лиц с назначения папой на назначение императором.

«Дар Константина - ложь и еретическая басня, над которой смеются в Риме торговцы и женщины, и апостолический муж со своими кардиналами от стыда не смеет показаться в городе» ${ }^{6}$, - пишет современник о легитимности притязаний папы Римского на часть территории Рима. Авторитет римской церкви упал очень низко. «Я утверждаю в пользу того, чтобы священники в мире не воевали и не совершали убийств», - пишет все тот же сенатор-современник императору Конраду. Вальвассоры-революционеры обещали поддержку императору и светским феодалам, пытаясь с их помощью лишить власти духовное сословие, однако император Фридрих Барбаросса помог римской церкви в лице папы и ввел свои войска в Рим, положив конец революции. Все достижения переворота 1143 года оказались уничтожены, папская власть была восстановлена, арнольдисты были признаны еретиками. Примирения с папой вальвассоры и арнольдисты искать не стали, поскольку Арнольд Брешианский был казнен в 1155 году именно по приказу папы Адриана IV. Реформа церкви осталась мечтой, и арнольдисты, пополнившие ряды еретиков гностического толка, вышли из политической жизни Италии, равно как и из духовной жизни католической церкви, предпочитая исповедоваться друг другу и не признавая папского клира.

Французский философ и богослов XIII-XIV вв. Дуранд описывает отношение арнольдистов к власти, а в частности, к власти Церкви, так: «Вероломные еретики арнольдисты говорят, что нигде не написано, чтобы Христос отдавал невесту Свою - Церковь - под охрану нечистых и роскошествующих служителей или чтобы он передал им власть совершать священные таинства, или ключи Царства, или власть вязать и разрешать» ${ }^{7}$. Отсюда следует, что основанием для приобретения власти вязать и разрешать, то есть власти духовной, является апостольская бедная жизнь. Арнольдисты, таким образом, не признавали легитимность всего духовного сословия именно по этому основанию.

К середине XII века катары уже широко распространились по Италии. Некоторые авторы, как утверждает Лев Карсавин, путали катаров с гибеллинами. Не исключено, что гибеллинов - противников

\footnotetext{
${ }^{6}$ Цит.по: Л.П. Карсавин. Указ.соч. С.79.

${ }^{7}$ Цит.по: Л.П. Карсавин. Указ.соч. С.81.
} 
папской власти и сторонников власти императора Священной Римской империи в Италии - считали еретиками именно потому, что гибеллины предоставляли убежище и кров своим естественным союзникам еретикам, которые, как и сами гибеллины, вели войну с папством. Изначально независимые взгляды гибеллинов и катаров зачастую переплетались, поскольку непротиворечили друг другу, и многие гибеллины обращались в катаризм. Так, «избиение инквизиторов» 1265 года, осуществленное гибеллинской партией, не могло обойтись без участия катаров. ${ }^{8}$

Милан был превращен в новую духовную столицу, став оппозицией Риму. Милан называли кафедрой Амвросия по имени Амвросия Медиоланского, крестившего Блаженного Августина. Кафедра Амвросия стала реальной альтернативой кафедре Петра в Риме. В это время уже весь север Италии, включая все крупные города, Брешию, Конкореццо, Баньоло, Винченцу, Верону, Витербо, Турин, Римини, Флоренцию и Милан, был охвачен ересью катаров, патаренов и вальденсов, чьи взгляды на религию, политику и общество были в целом схожи. В 1205 году катары оказались в составе консулов Витербо, а папа Иннокентий III в своей булле заявил: “Сыновья Велиала осмелились избрать консулами еретиков и не остановились перед тем, чтобы назначить даже городским казначеем ересиарха, сына погибели, Тиньози, который в силу своих злодеяний еще до сих пор связан, по нашему повелению, оковами отлучения и все еще, несмотря на это, упорствует в своем неповиновении" . Следует отметить, что Тиньози - знатный род из Витербо, исторически поддерживавший гибеллинов. Действия Джованни Тиньози и других катаров были, таким образом, направлены на уменьшение влияния папства в Витербо, прекращение кормления духовных феодалов - ставленников Рима. Тогда в Витербо случился не только духовный, но и политический перелом. С одной стороны, катары, проникшие в верхушку администрации Витербо, изгнали папских священников. С другой стороны, гибеллинская знать, бывшая в союзе с катарами, одержала политическую победу над пополанами (от итал. popolo - народ) - торгово-ремесленным сословием, стремившимся установить цеховую власть в отдельных городах Италии. Им удалось установить цеховой режим правления в виде олигархий в Болонье в 1245 и

\footnotetext{
${ }^{8}$ См. Л.П. Карсавин. Указ.соч. С.19.

${ }^{9}$ Цит. по: С.Г. Лозинский. История папства. - М.: Издательство политической литературы, 1986. С.161.
}

во Флоренции в 1250 годах. Даже личное присутствие в городе папы Иннокентия III, спровоцировавшее бегство патаренов из города, не уничтожило ереси в Витербо. Обещание папы передавать доходы от конфискаций имущества катарских семей на постройку стен города не соблазнило витербийцев предать столь близкие им по духу и политическим взглядам еретиков.

Всего Лев Карсавин насчитывает 16 городов, о которых точно известно о существовании в этих городах ереси. Члены еретических сект жили бок о бок друг с другом, не находя причин для серьезных разногласий. С примерно 1209 года до 1231 года в Риме даже существовала катарская школа, в которой открыто проповедовалось их учение. Мирян сожгли, а клириков-еретиков лишили сана. Этот случай лишний раз подтверждает широкое распространение ереси в итальянских государствах и их глубокое проникновение во все сферы жизни общества.

В 1225 году в Брешии гибеллины в союзе с катарами подняли открытый мятеж против духовной власти Рима. Знатные рода де Гамбара, Угони, Ботари, Ориани организовали оборону, разрушили таранами церкви и подготовили к бою башни. Даже глава администрации Брешии, подеста, встал на сторону восставших. Булла Гонория III разъясняет сложившуюся ситуацию и даже в некоторой степени оправдывает гибеллинов: «всеми способами стараясь оправдать вину свою и отсутствующих, утверждая, что государство брешианское уже давно разделилось на партии, как это известно, и что, если в их партии находятся люди, заподозренные в вышеназванном лжеучении, они стремились защищать их не как еретиков, а как членов своей партии» ${ }^{10}$. С одной стороны, ссылаясь на тесное переплетение гибеллинов и катаров, папа снисходительнее относится к гибеллинам, оправдывая их поступок губительным влиянием антиклерикальной ереси. С другой стороны, вмешивая в дело катаров, папа Гонорий III оправдывает свое перемирие с враждебной ему партией.

В XII веке катары создали такую же организованную церковь, как и католики, под руководством епископа Марка в Северной Италии (1167). Ломбардские и парижские катары ездят друг к другу на богословские конференции, поддерживаются связи с гностическим Востоком. Катары действуют открыто и без стеснения. В 1254 году в замке Гата в Ломбардии открывается катарская школа, занимающаяся вопро-

${ }^{10}$ Цит. по: Л.П. Карсавин. Указ.соч. С.27. 


\section{Политика и общество $7(103) \cdot 2013$}

сами богословия и права. В это же время Флоренция становится еще одним центром катаризма, но не идейным, а скорее военным. Семейство Барони объявило о покровительстве гностикам и о защите еретиков с оружием в руках при необходимости. Барони действительно спасли многих еретиков от тюрьмы, пряча их в своих башнях. ${ }^{11}$

Катарская церковь напоминала умеренно-дуалистическую церковь манихейского типа. Основания отделения церкви катаров от церкви католиков частично сформулировал «чистый» Пунгилуп: «...хорошие люди только еретики и те, кто идут их дорогою. [...] Смешно все, что говорят братья и пресвитеры римской церкви... Освященная гостия не тело Христово, а тесто... Как можно освятить тело Христово руками диавола, а ведь названные священники сотворены диаволом. Бог же не создал диавола и ничего не делает ниже неба, и все это мирское сотворено худым Богом, т. е. диаволом, потому что, если бы Бог создал диавола, он был бы участником всех земных зол. [...] Все, входящее в уста, идет в желудок и извергается в отхожее место. Но то, что церковь римская считает телом Христовым, идет в желудок. Следовательно, оно извергается в отхожее место, о чем смешно прямо говорить». ${ }^{12}$ Эти и многие другие сентенции, смущавшие католиков, заложили фундамент атеизма - явления, еще не характерного для общественного сознания средневековья.

Манихейские дуалистические концепции катаров были обозначены в докторской диссертации Л.П. Карсавина «Очерки средневековой религиозности»:

«Владыка века сего ослепил умы неверных, чтобы не сиял свет Евангелия славы Христовой». Ясно говорит апостол, что у другого мира другой Господь. И это вино из того, что он говорит «ослепил». А так как это, то есть ослеплять, чтобы не сиял и т. д. худо, оно может исходить только от худого. Но этот худой - Бог, как говорит апостол, следовательно, он - худой Бог. И ведь у Иоанна Христос сказал: «Царство Мое не от мира сего»; а у Луки написано: «Царству Его не будет конца», мир же прейдет, как это ясно из многих мест. Очевидно, что два мира и два Бога, добрый и злой, и от злого исходит все худое в нашем мире. Но вед и римская церковь - зло; это - общая мысль. Значит, и она - создание диавола и Ecclesia malignantium. А отсюда следует, что и таинства ее - не таинства (к этому уже приучило сомнение в их

\footnotetext{
${ }^{11}$ См. Л.П. Карсавин, указ.соч. С.39.

${ }^{12}$ Цит.по: Л.П. Карсавин, указ.соч. С.40.
}

действенности в руках дурного клирика); настоящие же таинства совершаются в морально чистой, святой церкви катаров. Еще один шаг далее. Сколько противоречий в Ветхом и Новом Заветах! «Слышали ли Вы, что сказано древним: “Возлюби ближнего твоего и ненавидь врага твоего” или: “Око за око, зуб за зуб»... Мог ли добрый Бог, заповедавший в Новом Завете совершенно противоположное, сказать эти слова? - Очевидно, нет. Следовательно, Бог Ветхого Завета - другой Бог, злой и несправедливый. Это Он творец всего худого в мире, от Него плотское вожделение, Ему предалась Римская церковь. Трудно ли после всех этих рассуждений, после этого хода мысли, которому нельзя отказать во внутренней логичности, отвергнуть все догмы христианства, понять Христа, как Мудрость, засмеяться над причастием?

Так от отрицания клира, от аскетизма и святой жизни, как идеалов, указанных Христом, незаметно совершается переход к дробящему мир и отвергающему римскую церковь дуализму, а от него к отвержению христианских догм и к догмам манихеев. ${ }^{13}$

Катары выстроили свою иерархию. Она состоит из епископа, «старшего сына», «младшего сына», дьякона. Вместе эти четыре сана образуют ordo, каждый из них является перфектом, «совершенным». Верующие не входят в катарскую церковь, стоят у ее порога. Их называли credentes, и с точки зрения перфектов, они были такими же грешниками, как и католики. В этом и есть сходство катаризма с манихейством: человек может творить любые грехи и жить не в соответствии с любыми социальными, религиозными и правовыми нормами. Не добродетель и не любовь главное в жизни «добрых христиан», как называли себя катары, а посвящение, consolamentum, уже упоминавшееся в отношении гностиков поздней античности и манихеев в частности. Катар достигал своего «совершенства» не путем долгого труда над собой, как это практикуется в христианской морали, а путем мгновенного переворота, сродни монашескому постригу, когда катар отрекается от всего земного и грешного. В момент consolamentum ему открываются врата в Рай. Поэтому большинство credentes принимали consolamentum только перед смертью, чтобы не тяготиться аскезой префектов. С одной стороны, такая позиция была в достаточной степени лицемерна, как и позиция манихеев. С другой стороны, достаточно при-

${ }^{13}$ Цит.по: Л.П. Карсавин, указ.соч. С.70-71. 
тягательна для широких кругов населения и была в опасной конкуренции с христианским учением.

Падение катаризма следует связать с влиянием правовых норм как средства регуляции на общественную, религиозную и политическую жизнь общества. Особенно велико влияние папских булл как источников права в средневековой Европе и в Италии в частности имеет большое значение. Буллы (от лат. bulla - «печать»). Такие документы издавались папами в случаях, требовавших особого вмешательства по вопросам духовной жизни. Что характерно, христианскими правителями, в адрес которых направлялись буллы, они исполнялись безусловно, в силу духовного авторитета Рима.

С другой стороны, стоит обратить внимание и на письменные источники права с другой стороны идейного противостояния. Это имперское законодательство. И если император мог быть справедливым и праведным христианином, высказывать почтение папе, то императорская партия гибеллинов периодически сама становилась жертвой антиеретических законов Священной Римской империи.

Законы, принятые Фридрихом II, чье правление пришлось на пик противостояния гностиков и католиков, по своей суровости не уступали эдиктам Феодосиева кодекса. Император развязал руки католическому духовенству накануне открытия инквизиционных трибуналов и дал клиру сильную нравственную и физическую поддержку.

Сразу же после помазания на царство 22 ноября 1220 г., Фридрих II принял крест из рук кардинала Уголино, будущего папы Иннокентия IV, принеся обет лично выступить в поход через полгода, и тут же, прямо в храме, подписал эдикт, составленный по указанию папы и имевший целью обезопасить духовенство и Церковь от всех врагов в империи. Тогда же папа, с высоты престола, произнес анафему против еретиков обоего пола, их укрывателей и защитников. ${ }^{14}$

В начале 1224 г. он написал свои конституции против еретиков. Шаги к примирению с папой являются одновременно шагами по созданию инквизиции.

Император давал знать всем духовным и светским судьям и должностным лицам, что еретики как «змеиные сыны вероломства, дерзающие оскорблять Бога и Церковь, как бы изгрызая тем утробу матери своей», должны быть предаваемы судам и юстиции. Из слов

${ }^{14}$ Н.А. Осокин. История альбигойцев и их времени. - М.: ACT, 2003. C.558. императора следует, что таких людей нельзя оставлять в живых. «Если в каком-либо месте империи будут выявлены еретики, то инквизиторы ... могут заставить судей схватить их и держать в крепком заточении до тех пор, пока, отлученные Церковью, они не будут осуждены и казнены. Все лица, имеющие какую-либо власть..., со своей стороны должны указывать упомянутым инквизиторам на подозрительных; те, кто оказывает покровительство и поддержку еретикам, также подвергаются смертной казни. [...] Такой же смертной казни подлежат и те, кто раньше отреклись от ереси, но после, сохранив жизнь, опять впали в нее.

Еретики отныне и даже до второго колена лишаются своих владений и объявляются неспособными к занятию каких-либо общественных должностей. И они, и дети их не могут пользоваться никакими почестями, хотя бы последние были сами по себе верными католиками; исключение делается только для тех детей, которые станут доносчиками на своих отцов. ${ }^{15}$

Падуанский статут Фридриха от 22 февраля 1224 г. почти полностью состоит из подбора ругательств в адрес еретиков, что было в духе времени; в дальнейшем теми же словами Фридрих отзывался о папах, для которых так усердно работал сейчас. ${ }^{16}$

Император также издавал ненормативные правовые акты частного характера - баны. Многие из них были направлены против еретиков.

Вплоть до начала активности инквизиции, борьба римско-католической церкви с еретиками шла посредством диспутов. Многие трактаты того времени, включая также «Сумму теологии» Фомы Аквинского были сборником готовых ответов на тезисы катаров, своего рода учебниками по спору с ними.

Невольно катарская ересь оказала большую услугу христианской церкви. Кроме уголовного преследования силою папских булл и императорских законов и банов, само католическое общество в среде простых верующих вырабатывало вакцину против ереси, средство для оздоровления общества.. Развивалась богословская литературная полемика, было написано множество трактатов на темы веры и ее места в обществе. Разрабатывались политико-правовые учения Фомы Аквинского, Монеты и других богословов. В 1223 году папа Гонорий III своей буллой

${ }^{15}$ CM. Die Konstitutionen Friedrichs II von Hohenstaufen für sein Königreich Sizilien: nach einer lateinischen Handschrift des 13. Jahrhunderts, Tom 1. - Böhlau, 1973. 355 p.

${ }^{16}$ Н.А. Осокин, указ.соч. С. 562. 


\section{Политика и общество $7(103) \cdot 2013$}

утвердил создание ордена францисканцев - нищенствующего монашеского ордена, проповедовавшего любовь к ближним и аскетизм. Францисканцы заняли достойное место в европейском обществе и обратили на себя внимание тех католиков, которые желали видеть в вере апостольскую бедность и идеалы раннего христианства. Орден св.Франциска отвлек внимание верующих от катарских префектов, которых любили как раз за аскезу и апостольскую бедность. Эти добродетели смиренных перфектов заставляли ярче проступать таким свойствам католических священников, как обмирщенность, прелюбодейство и политическая пристрастность. Катары вскрывают эти пороки клира и делают его лучше.

На почве борьбы с катаризмом появляются общественные организации в организационно-правовой форме ассоциаций. Одна из крупных ассоциаций была создана в Парме в 1233 году, получив поощрение папы.

Не везде борьба с ересью шла успешно. Генуя была принуждена к изменению законодательства о еретиках папой путем угрозы интердикта (запрещения богослужений). 1209-1229 годы ознаменовались печальным событием для всего католического мира и одним из самых кровавых политических событий средневековья - Альбигойским крестовым походом. Объявленный папой на земли графа Тулузского, покровительствовавшего еретикам, этот крестовый поход, направленный в самое сердце христианской Европы, унес жизни более миллиона человек, что довольно существенно для XIII века. На фоне Пятого крестового похода, который шел в одно время с Альбигойским и выступления на стороне катаров короля Арагона Педро II, Альбигойский крестовый поход является важным политическим событием начала XIII века. Уничтожение тулузской династии, не покаявшейся в катаризме, привело к переходу Окситании (южную часть современной Франции) в королевский дом Франции. Жестокость с обеих сторон, как среди катаров, так и среди католиков, нетерпимость и фанатизм положили начало активной деятельности инквизиции. Пытки и мучительные казни людей вне зависимости от пола, возраста и состо- яния здоровья стали с тех пор обычным делом для инквизиционных процессов. Вплоть до Нового времени философией, определяющей политико-правовое сознание Европы стал католицизм.

\section{Библиография:}

1. Карсавин, Л.П. Очерки средневековой религиозности // История ересей: [сб.] / сост. А. Лактионов. - М.: АСТ, 2007.

2. Лозинский, С.Г. История папства / С.Г. Лозинский - М.: Издательство политической литературы, 1986.

3. Осокин, Н.А. История альбигойцев и их времени / Н.А. Осокин - М.: АСТ, 2003.

4. Annales barenses // MGH, SS. Bd. V. Hannover. 1844.

5. Die Konstitutionen Friedrichs II von Hohenstaufen für sein Königreich Sizilien: nach einer lateinischen Handschrift des 13. Jahrhunderts, Tom 1.-Böhlau, 1973

6. Rodulfi Glabri Historiarum Libri Quinque; Rodulfus Glaber, The Five Books of the Histories [cover title: Rodulfus Glaber, Opera] ed. J. France (Oxford, 1989).

\section{References (transliteration):}

1. Karsavin, L.P. Ocherki srednevekovoy religioznosti // Istoriya eresey: [sb.] / sost. A. Laktionov. - M.: AST, 2007.

2. Lozinskiy, S.G. Istoriya papstva / S.G. Lozinskiy M.: Izdatel'stvo politicheskoy literatury, 1986.

3. Osokin, N.A. Istoriya al'bigoycev $\mathrm{i}$ ih vremeni / N.A. Osokin - M.: AST, 2003.

4. Annales barenses // MGH, SS. Bd. V. Hannover. 1844.

5. Die Konstitutionen Friedrichs II von Hohenstaufen für sein Königreich Sizilien: nach einer lateinischen Handschrift des 13. Jahrhunderts, Tom 1.-Böhlau, 1973

6. Rodulfi Glabri Historiarum Libri Quinque; Rodulfus Glaber, The Five Books of the Histories [cover title: Rodulfus Glaber, Opera] ed. J. France (Oxford, 1989). 